\title{
Oral paclitaxel chemotherapy for brain tumors: Ideal combination treatment of paclitaxel and P-glycoprotein inhibitor
}

\author{
KYEUNG MIN JOO ${ }^{1,3^{*}}$, KWAN PARK ${ }^{1 *}$, DOO-SIK KONG ${ }^{1}$, SANG YONG SONG ${ }^{2}$, \\ MI HYUN KIM ${ }^{1}$, GWAN SUN LEE ${ }^{4}$, MAENG SUP KIM ${ }^{4}$ and DO-HYUN NAM ${ }^{1}$ \\ Departments of ${ }^{1}$ Neurosurgery and ${ }^{2}$ Pathology, Samsung Medical Center and \\ Samsung Biomedical Research Institute, Sungkyunkwan University School of Medicine, Seoul; \\ ${ }^{3}$ National Institute of Science Investigation, Seoul; ${ }^{4}$ Hanmi Pharm. Co., Seoul, Korea
}

Received August 8, 2007; Accepted August 31, 2007

\begin{abstract}
Oral chemotherapy has many advantages over parenteral chemotherapeutics administration. To use the advantages of the oral chemotherapy and maximize anti-tumor effects of the chemotherapeutic agent, we designed HM30181A (a P-glycoprotein inhibitor) and a paclitaxel oral co-administration chemotherapeutic method. HM30181A is used to aid paclitaxel absorption from gut lumen into blood and to inhibit paclitaxel exclusion out of the brain tumor mass by endothelial cells, which inhibits paclitaxel access to tumor cells in the brain parenchyma. We applied HM30181A and paclitaxel oral co-administration methods to the treatment of tumors in the brain using the K1735 melanoma brain metastasis animal model and the U-87 MG glioblastoma animal model. Administrations were performed twice per week for 28 days and the therapeutic effect was examined using tumor volume change. We observed that $32 \mathrm{mg} / \mathrm{kg}$ HM30181 A and $16 \mathrm{mg} / \mathrm{kg}$ of paclitaxel (dose ratio 2:1) oral co-administration showed significant therapeutic effects in both animal models, but when the doses or dose ratio was changed, the effects could not be observed. Therefore, adjustments of doses and dose ratio of the agents seems to be essential in realizing oral HM30181 A and paclitaxel treatment in brain tumors. These results suggest that if the doses and dose ratio can be successfully adjusted, the oral coadministration of HM30181A and paclitaxel can be used to treat tumors in the brain.
\end{abstract}

Correspondence to: Dr Do-Hyun Nam, Department of Neurosurgery, Samsung Medical Center and Biomedical Research Institute, Sungkyunkwan University School of Medicine, \#50, Irwon-dong, Gangnam-Gu, Seoul 135-710, Korea

E-mail: nsnam@smc.samsung.co.kr

${ }^{*}$ Contributed equally

Key words: paclitaxel, brain tumors, P-glycoprotein

\section{Introduction}

$\mathrm{P}$-glycoprotein $(\mathrm{P}-\mathrm{gp})$ is known to be one of the most important active efflux transporters for drug disposition in humans $(1,2)$. P-gp was first reported in tumor cells (3) but it is also present in non-tumor tissues such as brain endothelial cells, which are a constituent of the blood-brain barrier (BBB) (4). As a result of complex tight junctions that cause severe restriction of the paracellular pathway, $\mathrm{BBB}$ is much tighter than peripheral microvessels. Therefore penetration across $\mathrm{BBB}$ is confined to transcellular mechanisms (5). But, due to $\mathrm{P}-\mathrm{gp}$ on the luminal side of plasma membrane in brain endothelial cells $(4,6)$, P-gp substrates hardly penetrate into the brain parenchyma through brain endothelial cells. The importance of P-gp at BBB was demonstrated by P-gp knockout mice $(7,8)$. The penetration of vinblastine into the brain was 7-46 fold higher in the knockout mice than in the wild-type controls (9). For this reason, many cytotoxic agents which are P-gp substrates cannot reach tumor cells in the brain parenchyma, and cannot make their effects even though tumor cells do not express P-gp $(10,11)$. Therefore, inhibition of P-gp activity of the brain endothelial cells should be an important factor that increases their anti-tumor effects.

Oral chemotherapy has many advantages such as flexibility of timing and location of administration, flexibility of drug exposure (providing more prolonged drug exposure compared with intermittent intravenous infusion), reduction of the use of healthcare resources for inpatient and ambulatory patient care services and a better quality of life (12). Oral chemotherapy is also good for the metronomic (anti-angiogenic) chemotherapy $(13,14)$, because this can maintain a low serum level of the chemotherapeutic agent for a longer time than parenteral routes. Metronomic chemotherapy uses antiangiogenic effects of cytotoxic agents and shows better therapeutic results in several tumor types $(13,14)$. However, $\mathrm{P}$-gp expressed in the luminal side of plasma membrane of gut epithelial cells prevents P-gp substrate chemotherapeutic agents from adsorption in the gut (15). In addition, metronomic chemotherapy is expected to be ineffective on tumors in the brain because P-gp expression on the brain endothelial cells extruded cytotoxic agents out of endothelial 
cells. For these reasons, phase II trial of metronomic chemotherapy using etoposide, cyclophosphamide, or thalidomide and celecoxib did not show good effects on malignant glioma (16).

Paclitaxel is a potent chemotherapeutic agent that has been reported to have therapeutic effects on several solid organ tumors such as ovarian, breast, non-small cell lung cancer and head and neck cancer (17) as well as having direct antiangiogenic effects (18-20). These properties of paclitaxel create expectations that paclitaxel could be a good therapeutic agent in the treatment of brain tumors. But as paclitaxel is one of the P-gp substrates (21-23), it cannot reach tumor cells in the brain parenchyma (24), which makes it hard to absorb orally administered paclitaxel from the gut lumen (15). Therefore, inhibition of P-pg activity is essential. To realize oral paclitaxel chemotherapy for tumors in the brain, we designed a new therapeutic method that uses co-administration of a recently developed P-gp inhibitor, HM30181 A $(25,26)$ and paclitaxel orally. We examined the therapeutic effects of this new method using two animal brain tumor models. One was a melanoma brain metastasis model and the other a primary glioblastoma model. Indeed oral co-administration of HM30181A and paclitaxel showed significant therapeutic effects in both animal brain tumor models. We found that to realize this therapy, the doses and dose ratio of HM30181A and paclitaxel are very important.

\section{Materials and methods}

Chemicals and cell culture. HM30181A (Cas\# 849675-87-2) were kindly provided by Hanmi Pharm. Co. (Seoul, Korea). Paclitaxel was purchased from Bristol-Myers Squipp Company (New York, NY). The mouse melanoma cell line, K1735 was acquired from Dr I.J. Fidler (The University of Texas, M.D. Anderson Cancer Center, Houston, TX). K1735 and the human glioblastoma cell line, U-87 MG (HTB-14, American Type Culture Collection, Manassas, VA), were maintained with a medium comprising of Roswell Park Memorial Institute (RPMI)-1640 (Cambrex, East Rutherford, NJ) and Minimum Essential Medium (MEM, Cambrex), respectively, supplemented with $10 \%$ fetal bovine serum and antibiotics (LIFE tech, Stafford, TX).

Animals and intracerebral implantation of tumor cells. Specific pathogen-free male $\mathrm{C} 3 \mathrm{H}$ and nude mice (Jackson Laboratory, Japan) were used for K1735 and U-87 MG, respectively. All animal work was approved by the Association for Assessment and Accreditation of Laboratory Animal Care International and in accordance with current regulations and standards of the Laboratory of Animal Research Center under Samsung Biomedical Research Institute. Intracerebral implantation of K1735 melanoma and U-87 MG glioblastoma cells was performed as described previously (27). Briefly, 6-7 week-old mice were anesthetized with an intraperitoneal injection of $100 \mathrm{mg} / \mathrm{kg}$ ketamin and $10 \mathrm{mg} / \mathrm{kg}$ xylazine. The heads of the anesthetized mice were shaved and disinfected with a solution of $70 \%$ ethyl alcohol and povidone iodine. They were secured in a rodent stereotactic frame, and a hollow guide screw was implanted into a small drill hole made at $2 \mathrm{~mm}$ left and $1 \mathrm{~mm}$ anterior to the bregma. K1735 melanoma cells
( $5 \times 10^{4}$ cells/10 $\left.\mu 1 \mathrm{HBSS}\right)$ or U-87 MG glioblastoma cells ( $2 \times 10^{5}$ cells $/ 5 \mu 1 \mathrm{HBSS}$ ) were injected through this guide screw into the white matter at a depth of $2 \mathrm{~mm}$ using a $10 \mu \mathrm{l}$ Hamilton syringe.

Drug administration. One day after the intracerebral injections, groups of mice were randomly assigned to receive the following treatments. K1735 cells injected $\mathrm{C} 3 \mathrm{H}$ mice had one of following 8 treatments: a) oral administration of P-gp inhibitor vehicle (PEG200-HCl 15\%, Control, $\mathrm{n}=5$ ) b) oral administration of $8 \mathrm{mg} / \mathrm{kg}$ of paclitaxel $(\mathrm{n}=4) \mathrm{c})$ oral administration of $16 \mathrm{mg} / \mathrm{kg}$ of HM30181A $(\mathrm{n}=4) \mathrm{d})$ oral administration of $32 \mathrm{mg} / \mathrm{kg}$ of HM30181A $(\mathrm{n}=4)$ e) oral administration of $48 \mathrm{mg} / \mathrm{kg}$ of HM30181A (n=4) f) oral administration of $16 \mathrm{mg} / \mathrm{kg}$ of HM30181 A and $8 \mathrm{mg} / \mathrm{kg}$ paclitaxel $(\mathrm{n}=5) \mathrm{g}$ ) oral administration of $32 \mathrm{mg} / \mathrm{kg}$ of HM30181 A and $16 \mathrm{mg} / \mathrm{kg}$ of paclitaxel $(\mathrm{n}=5)$ or $\mathrm{h})$ oral administration of $48 \mathrm{mg} / \mathrm{kg}$ of HM30181A and $32 \mathrm{mg} / \mathrm{kg}$ of paclitaxel $(n=5)$. U-87 MG cells injected nude mice had one of following 7 treatments: a) oral administration of P-gp inhibitor vehicle $(\mathrm{n}=7)$ b) oral administration of $16 \mathrm{mg} / \mathrm{kg}$ of HM30181A $(\mathrm{n}=5) \mathrm{c})$ oral administration of $32 \mathrm{mg} / \mathrm{kg}$ of HM30181 A $(\mathrm{n}=5) \mathrm{d})$ oral administration of $16 \mathrm{mg} / \mathrm{kg}$ of HM30181A and $8 \mathrm{mg} / \mathrm{kg}$ of paclitaxel $(\mathrm{n}=7)$ e) oral administration of $32 \mathrm{mg} / \mathrm{kg}$ of HM30181 A and $8 \mathrm{mg} / \mathrm{kg}$ of paclitaxel $(\mathrm{n}=7) \mathrm{f}$ ) oral administration of $16 \mathrm{mg} / \mathrm{kg}$ of HM30181 A and $16 \mathrm{mg} / \mathrm{kg}$ of paclitaxel $(\mathrm{n}=7)$ or $\mathrm{g}$ ) oral administration of $32 \mathrm{mg} / \mathrm{kg}$ of HM30181A and $16 \mathrm{mg} / \mathrm{kg}$ of paclitaxel $(n=7)$. All treatments were performed twice per week for 28 days.

Specimen harvest and tumor volume measurement. At the end of treatments the mice were sacrificed. The brains were removed and sliced into 4-6 mm-thick blocks. For tumor volume measurement, blocks were fixed in $10 \%$ phosphatebuffered saline (PBS), buffered formalin and embedded in paraffin. For immunohistochemistry and terminal deoxynucleotidyl transferase biotin-dUTP nick end-labeling (TUNEL) assay, other blocks were embedded in OCT compound (Miles. Inc., Elkhart, IN), frozen rapidly in liquid nitrogen and stored at $-70^{\circ} \mathrm{C}$. The blocks for the tumor volume assessment were sliced into $4 \mu \mathrm{m}$ coronal sections using a microtome and H\&E staining was performed. The tumor volume was calculated by measuring the section with the largest tumor portion with the formula: width $^{2} \mathrm{x}$ length $\mathrm{x} 0.5$.

Immunohistochemistry and TUNEL assay. The blocks were sliced into $8 \mu \mathrm{m}$ coronal sections using a cryostat. Sections were thaw-mounted onto gelatine chromalum-coated glass slides and fixed with acetone for $5 \mathrm{~min}$. Immunohistochemistry was performed as described previously (27). Briefly, sections were permeabilized by incubation for $15 \mathrm{~min}$ in freshly prepared $0.2 \%$ Triton X-100/PBS, pre-incubated for $1 \mathrm{~h}$ in PBS containing 5\% normal goat serum, and then incubated for $2 \mathrm{~h}$ in diluted mouse anti-P-gp monoclonal antibody (1:50, M3521, Dako, Glostrup, Denmark) and/or rat anti-mouse CD31/PECAM-1 monoclonal antibody (1:200, 557355, BD Pharmingen, Franklin Lakes, NJ) in PBS containing $5 \%$ goat serum. Immunostaining was carried out by incubation for $1 \mathrm{~h}$ in 1:200 diluted Alexa-594-labeled goat 



Figure 1. P-gp expression on the normal brain endothelial cells and endothelial cells in K1735 melanoma and U-87 MG glioblastoma brain mass. Tissues from normal brain (left), K1735 melanoma (middle) and U-87 MG glioblastoma brain mass (right) were stained with anti-CD31/PECAM-1 antibody (red), anti-P-gp antibody (green) and DAPI (blue, nuclei). CD31/P-gp double labels are shown in yellow. Scale bar $=50 \mu \mathrm{m}$.

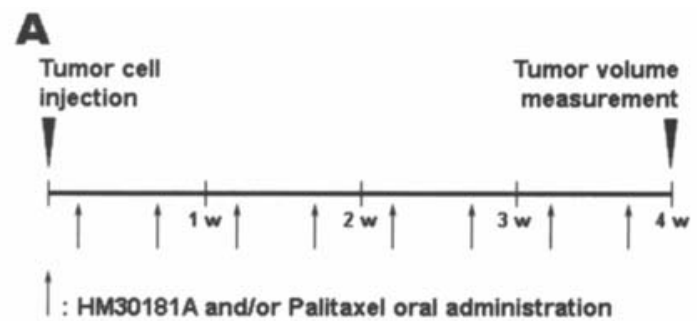

$\mathbf{B}$

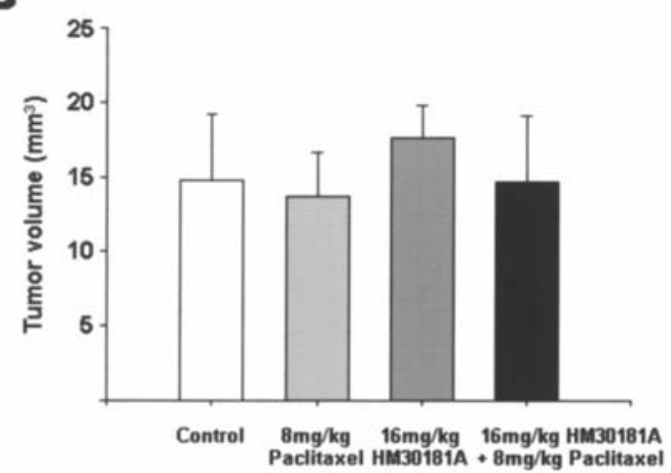

Figure 2. Drug administration schedule and therapeutic effects of HM30181A and paclitaxel oral co-administration on the melanoma brain metastasis model. (A) Drug administrations were started one day after tumor cells intracerebral injections. Paclitaxel and HM30181A oral treatment was performed twice per week for four weeks. Tumor volume was measured 4 weeks after the injection. (B) Means of tumor volumes of K1735 brain tumor masses 4 weeks after intracerebral injection. Error bar $=$ standard deviation. Sixteen $\mathrm{mg} / \mathrm{kg}$ of HM30181 A and $8 \mathrm{mg} / \mathrm{kg}$ of paclitaxel oral co-administration methods showed no reduction of tumor volume, compared with control, $8 \mathrm{mg} / \mathrm{kg}$ paclitaxel oral and $16 \mathrm{mg} / \mathrm{kg}$ HM30181 A oral administration group.

anti-rat IgG and/or Alexa-488-labeled goat anti-mouse IgG antibody (Invitrogen Co., Carsbad, CA). TUNEL assay was performed using the DeadEnd fluorometric TUNEL system (\#G3250, Promega, Madison, WI) according to the manufacturer's protocol.

Data analysis. To quantify immunostaining for TUNEL assays, numbers of stained cells were counted in ten random fields at $\mathrm{x} 400$. Statistical comparisons between groups were performed using the Student's t-test. Values of $\mathrm{P}<0.05$ were considered statistically significant.

\section{Results}

P-gp expression on brain endothelial cells and endothelial cells of K1735 and U-87 MG brain tumor mass. To confirm that endothelial cells in K1735 melanoma and U-87 MG glioblastoma brain mass express P-gp, the P-gp expression was compared with that of the normal brain endothelial cells. As shown in Fig. 1 (left panel), almost all brain endothelial cells express a high level of P-gp (red = CD31/PECAM-1, green $=\mathrm{P}-\mathrm{gp}$ ). Compared with the normal brain endothelial cells, endothelial cells in K1735 melanoma (Fig. 1, middle panel) and U-87 MG glioblastoma brain mass (Fig. 1, right panel) expressed similar levels of P-gp.

Animal models and schedule of drug administration. Melanoma brain metastasis and primary glioblastoma animal models were made by intracerebral injection of K1735 melanoma cells $\left(5 \times 10^{4}\right.$ cells $\left./ 10 \mu 1 \mathrm{HBSS}\right)$ or U-87 MG glioblastoma cells $\left(2 \times 10^{5}\right.$ cells/5 $\mu 1$ HBSS $)$, respectively. Drug administrations were started one day after the injections. To maximize the anti-angiogenic effect, the oral paclitaxel administration method was chosen and to help paclitaxel adsorption the P-gp inhibitor, HM30181A, was coadministered with paclitaxel. Paclitaxel and HM30181A oral treatment was performed twice per week for four weeks (Fig. 2A).

Therapeutic effect of the paclitaxel and HM30181A oral coadministration and importance of the doses and dose ratio. At first, we designed $16 \mathrm{mg} / \mathrm{kg} \mathrm{HM} 30181 \mathrm{~A}$ and $8 \mathrm{mg} / \mathrm{kg}$ of paclitaxel oral co-administration methods and examined the therapeutic effects of this new modality in melanoma brain metastasis animal model compared with the control (oral administration of HM30181A vehicle, PEG200-HCl 15\%), $8 \mathrm{mg} / \mathrm{kg}$ of paclitaxel oral administrated and $16 \mathrm{mg} / \mathrm{kg}$ of HM30181A oral administrated group. However, when brain mass volumes were measured after 4 weeks of treatment no differences in the tumor volume were observed (Fig. 2B). We 
A

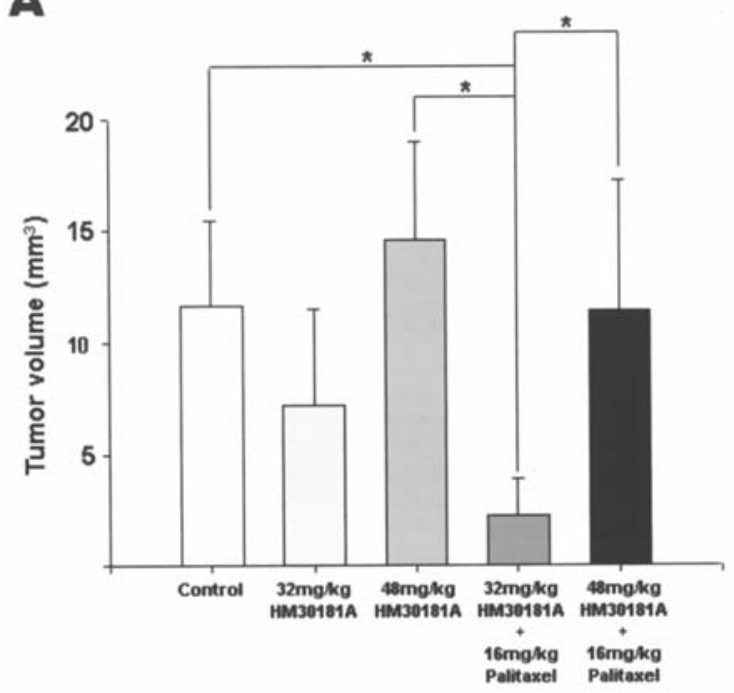

K1735 brain tumor mass
$\mathbf{B}$

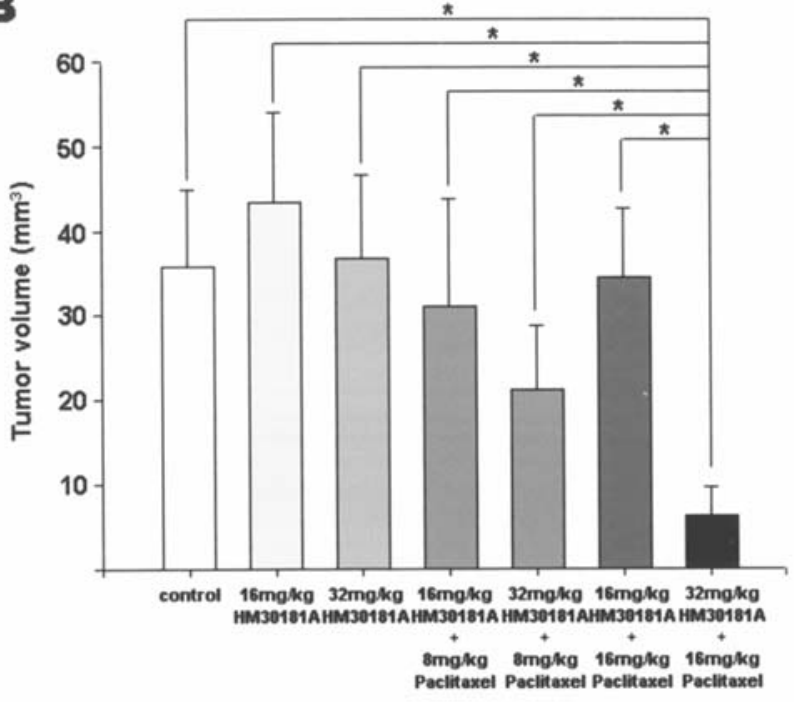

U-87 MG brain tumor mass

Figure 3. Therapeutic effects of HM30181A and paclitaxel oral co-administration on tumors in the brain. Graphs show means of tumor volumes of K1735 (A) or U-87 MG (B) brain tumor masses 4 weeks after intracerebral injection. Error bar, standard deviation. (A) Melanoma brain metastasis model. Only oral administration of $32 \mathrm{mg} / \mathrm{kg}$ HM30181 A and $16 \mathrm{mg} / \mathrm{kg}$ paclitaxel showed a statistically significant treatment effect. ${ }^{*} \mathrm{P}<0.05$. (B) Primary glioblastoma animal model. Among various treatment methods, only $32 \mathrm{mg} / \mathrm{kg} \mathrm{HM} 30181 \mathrm{~A}$ and $16 \mathrm{mg} / \mathrm{kg}$ paclitaxel oral co-administration showed a statistically significant volume reduction of $\mathrm{U}-87 \mathrm{MG}$ brain tumor mass. ${ }^{*} \mathrm{P}<0.05$.
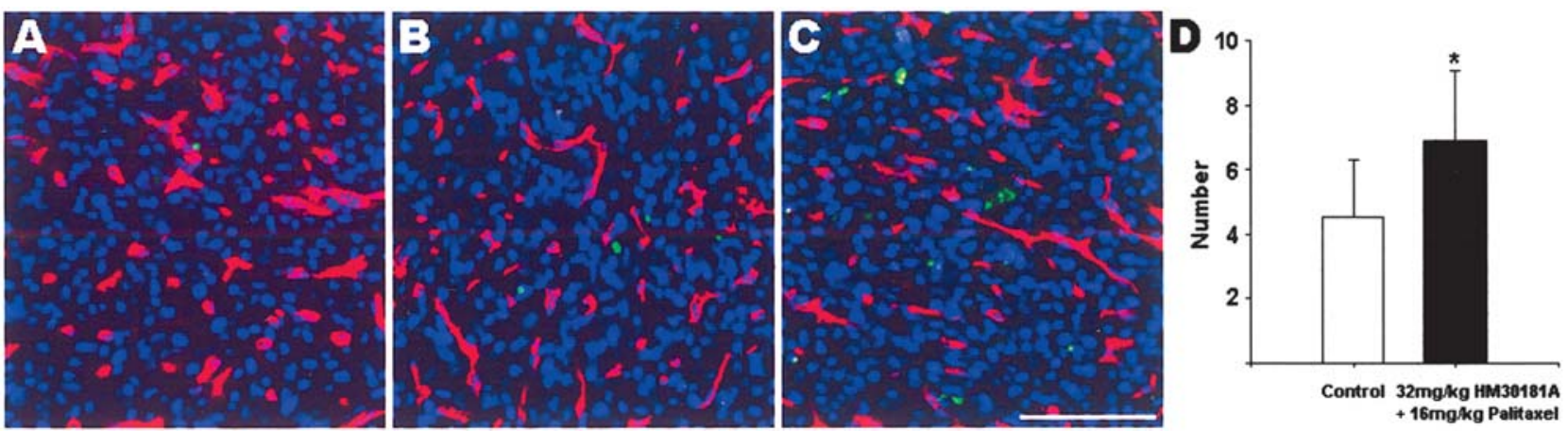

Figure 4. Simultaneous immunohistochemistry using anti-CD31/PECAM-1 antibody and TUNEL assay. (A-C) Immunohistochemistry using antiCD31/PECAM-1 antibody and TUNEL assay were done simultaneously on the sections from K1735 brain tumor masses (A: control group; B: paclitaxel 8 mg/kg oral treatment group, C: $32 \mathrm{mg} / \mathrm{kg}$ HM30181A and $16 \mathrm{mg} / \mathrm{kg}$ paclitaxel oral co-treatment group). CD31/PECAM-1, red; TUNEL, green; DAPI, blue nuclei. Scale bar, $50 \mu \mathrm{m}$. (D) Numbers of TUNEL stained cells were counted in ten random fields at x400. The graph shows means of TUNEL-labeled cell numbers. Error bar, standard deviation. TUNEL labeled cell number was significantly increased in the $32 \mathrm{mg} / \mathrm{kg} \mathrm{HM} 30181 \mathrm{~A}$ and $16 \mathrm{mg} / \mathrm{kg}$ paclitaxel oral co-treated group. ${ }^{*} \mathrm{P}<0.05$.

thought this ineffectiveness could be due to very low doses of the drugs and/or dose mismatch. So, another two new treatment methods were designed which were $32 \mathrm{mg} / \mathrm{kg}$ $\mathrm{HM} 30181 \mathrm{~A}$ and $16 \mathrm{mg} / \mathrm{kg}$ of paclitaxel oral co-administration and $48 \mathrm{mg} / \mathrm{kg} \mathrm{HM} 30181 \mathrm{~A}$ and $16 \mathrm{mg} / \mathrm{kg}$ of paclitaxel oral co-administration. When these treatments were examined as shown in Fig. 2A, statistically significant tumor volume reduction was observed only in the $32 \mathrm{mg} / \mathrm{kg}$ HM30181A and $16 \mathrm{mg} / \mathrm{kg}$ of paclitaxel oral co-administration group (Fig. 3A, $\mathrm{P}<0.05$ ).

Using a melanoma brain metastasis model, we found that HM30181A and paclitaxel oral co-administration has therapeutic effects on tumors in the brain and for this effect, the doses of each drug (32 mg/kg HM30181A, $16 \mathrm{mg} / \mathrm{kg}$ of paclitaxel) and dose ratio (HM30181A:paclitaxel 2:1) is very important. To confirm the therapeutic effect of the method on tumors in the brain, we tested the effect of $32 \mathrm{mg} / \mathrm{kg}$ HM30181 A and $16 \mathrm{mg} / \mathrm{kg}$ of paclitaxel oral co-administration method using another animal model, primary glioblastoma model and the importance of the doses and dose ratio was checked once again. Numerous combination therapies of HM30181A and paclitaxel were performed according to the schedule in Figs. 2A and 3B. As the melanoma brain metastasis model, only oral administration of $32 \mathrm{mg} / \mathrm{kg}$ HM30181 A and $16 \mathrm{mg} / \mathrm{kg}$ of paclitaxel showed a statistically significant treatment effect in the primary glioblastoma animal model (Fig. 3B, $\mathrm{P}<0.05$ ).

Increased tumor cell apoptosis in the $32 \mathrm{mg} / \mathrm{kg} \mathrm{HM30181 \textrm {A }}$ and $16 \mathrm{mg} / \mathrm{kg}$ of paclitaxel co-treated brain tumor mass. To 
find the mechanism of the $32 \mathrm{mg} / \mathrm{kg}$ of HM30181A and 16 $\mathrm{mg} / \mathrm{kg}$ paclitaxel oral co-treatment, immunohistochemistry using anti-CD31/PECAM-1 antibody (red in Fig. 4A-C) and TUNEL assay (green in Fig. 4A-C) were done simultaneously on the sections from K1735 (Fig. 4A-C) and U-87 MG brain tumor masses. As shown in Fig. 4A-C (A: control; B: paclitaxel $8 \mathrm{mg} / \mathrm{kg}$, C: $32 \mathrm{mg} / \mathrm{kg}$ HM30181A and $16 \mathrm{mg} / \mathrm{kg}$ of paclitaxel), there was little difference in CD31 immunoreactivity. But more tumor cells labeled by the TUNEL assay were observed in the $32 \mathrm{mg} / \mathrm{kg} \mathrm{HM} 30181 \mathrm{~A}$ and $16 \mathrm{mg} / \mathrm{kg}$ of paclitaxel oral co-administration group (Fig. 4C) compared with the other groups [only control (Fig. 4A) and $8 \mathrm{mg} / \mathrm{kg}$ of paclitaxel oral treated (Fig. 4B) group are presented]. When numbers of TUNEL stained cells were counted in ten random fields at $\mathrm{x} 400$, the differences were statistically significant (Fig. 4D). The same observation was found once more in the glioblastoma animal model, although the results are not shown in Fig. 4. Therefore $32 \mathrm{mg} / \mathrm{kg}$ of HM30181A and $16 \mathrm{mg} / \mathrm{kg}$ of paclitaxel oral co-treatment seems to increase apoptosis of tumor cells by promoting the penetration of paclitaxel through the blood tumor barrier which expresses P-gp.

\section{Discussion}

The present study using two kinds of brain tumor animal models [K1735 melanoma brain metastasis model (Figs. 2B and 3A) and the U-87 MG glioblastoma model] (Fig. 3B), showed that oral co-administration of a P-pg inhibitor, HM30181A, and paclitaxel can be successfully applied to the treatment of tumors in the brain. But the doses and dose ratio of HM30181A and paclitaxel should be finely adjusted because the therapeutic effects in the brain tumor animal models were observed only in $32 \mathrm{mg} / \mathrm{kg}$ of HM30181 A and $16 \mathrm{mg} / \mathrm{kg}$ of paclitaxel co-treatment (dose ratio 2:1; Figs. 2 and 3 ). The therapeutic effects of co-administration of HM30181A and paclitaxel may be based on the increased apoptosis of tumor cells, since the number of TUNEL labeled tumor cells was significantly increased (Fig. 4).

Oral administration of paclitaxel was planned to maximize the chemotherapeutic effects of paclitaxel (18). However, because P-gp is expressed on the luminal side of plasma membrane of gut epithelial cells (15), paclitaxel cannot be absorbed from gut lumen. In addition, P-gp on the endothelial cells in melanoma brain metastasis (Fig. 1, middle panel) and glioblastoma (Fig. 1, right panel) $(28,29)$ extrudes paclitaxel out of the tumor parenchyma, which abolishes the anti-tumor activity of paclitaxel. To overcome these obstacles, we designed a co-administration of paclitaxel and a new P-gp inhibitor, HM30181 A (Fig. 2A). HM-30181A is 4H-1Benzopyran-2-carboxmide, N-[2-[2-\{4-[2-(3,4-dihydro-6,7dimethoxy-2(1H)-isoquinolinyl)-ethyl]phenyl $\}-2 \mathrm{H}$-tetrazol-5yl]-4,5-dimethoxyphenyl]-4-oxo-, mesylate and competitively inhibits P-gp $(25,26)$. In a recent report $(25)$, we proved that oral co-administration of HM30181A and paclitaxel to male Sprague-Dawley rats allows paclitaxel to be adsorbed into the blood successfully. Therefore, HM30181A and paclitaxel oral co-administration could be a good choice in an attempt to increase the absorption rate of paclitaxel.

Although HM30181A and paclitaxel oral co-treatment was designed to have both paclitaxel direct cytotoxic effect on tumor cells in the brain parenchyma and anti-angiogenic effect on the brain endothelial cells, only direct apoptosis inducing effects on tumor cells were observed (Fig. 4). In terms of metronomic chemotherapy, increased endothelial cell apoptosis and the resulting reduction in new vessel formation induce tumor cell apoptosis $(13,14)$. But, even with the distracted schedule of oral paclitaxel chemotherapy (Fig. 2A), we did not detect endothelial cell apoptosis. Instead, we observed many apoptotic tumor cells, which suggests that HM30181A inhibits the pumping out mechanism of P-gp of the brain endothelial cells and enables paclitaxel to penetrate into the parenchyma of the brain tumors. Although, there is no evidence of the anti-angiogenic effects in the therapy in this research, the addition of anti-angiogenic agents such as endothelial cell survival factor inhibitors may potentiate the anti-angiogenic effects of the metronomic dose of paclitaxel oral treatment.

In this study, we found that adjustments of doses and dose ratio of the agents are very important in realizing oral HM30181 A and paclitaxel treatment on tumors in the brain. Because HM30181A is a competitive inhibitor of P-gp $(25,26)$, it is reasonable that a low amount of HM30181 A cannot effectively inhibit P-gp and this makes the therapy ineffective, but a high dose of HM30181A also had no effect in this study (Fig. 3). We cannot explain this result with the exact mechanisms. However, very high levels of HM30181 A might activate metabolism and/or excretion of paclitaxel. Reactive P-gp overexpression in the gut epithelium or brain endothelial cells might also occur in response to high dose HM30181 A administration. To support this possibility, it was previously reported that $\mathrm{P}$-gp expression is induced when cells are exposed to various toxic xenobiotics (30-31) or dugs (31-34) and applying a P-gp inhibitor, verapamil, also increases its expression (35). There are ideal doses and dose ratios of HM30181A and paclitaxel and they should be considered when oral paclitaxel treatment with P-gp inhibitor clinical trial is planned.

The ideal dose and dose ratio could be different according to the type and environment of tumors. According to the unpublished data from Hanmi Pharm. Co., the ideal dose ratio of HM30181A and paclitaxel was 1:1 in the treatment of breast cancer (breast cancer animal model in which mammary fat pads were injected with MCF-7 breast cancer cells). A major difference of breast cancer in mammary fat pad and tumors in the brain is P-gp expression on the endothelial cells. In contrast to the brain endothelial cells, endothelial cells in the subcutaneous tissue do not express $\mathrm{P}$-gp, therefore if paclitaxel is adsorbed from the gut lumen it can access the breast cancer cells freely. But to reach tumor cells in the brain parenchyma, paclitaxel should cross both P-gp expressing gut epithelial cells and brain endothelial cells. Regarding this difference, it can be postulated that twice as much of the competitive P-gp inhibitor, HM30181A, is needed for paclitaxel to reach the tumor cells in the brain. Therefore, the doses and dose ratio adjustment of HM30181A and paclitaxel should to be made differentially according to target tumors or organs.

There are many articles reporting that P-gp inhibitors disturb metabolism and/or excretion of chemotherapeutic agents (36). These disturbances make prediction of the serum 
levels very difficult, resulting in systemic side effects which took place even though conventional or reduced doses of chemotherapeutic agents were used. Due to this problem, many P-gp inhibitors, especially second generation P-gp inhibitors such as dexverapamil, dexniguldipine, valspodar (PSC 833), and biricodar (VX-710), failed to be used in the clinic (36). Because we used the P-gp inhibitor, there must be the possibility that systemic side effects may occur. But, we used oral paclitaxel administration, which maintains a lower paclitaxel serum level for a long period of time and increase and decrease the paclitaxel serum level more gradually. These effects of oral paclitaxel administration could lower the possibility of side effects, although there are significant therapeutic effects. In our study, no significant side effects were observed in the treated animals. Therefore, oral distracted administration of a chemotherapeutic agent with $\mathrm{P}-\mathrm{gp}$ inhibitor can be a good method that can overcome the fatal side effects of the P-gp inhibitor and can facilitate combinational treatment with other anti-angiogenic agents and/or signal transduction modulators.

For the first time, we designed HM30181A (a P-gp inhibitor) and paclitaxel oral co-administration method to treat tumors in the brain. We successfully applied HM30181A and paclitaxel oral co-administration method to the treatment of tumors in the brain and $32 \mathrm{mg} / \mathrm{kg} \mathrm{HM} 30181 \mathrm{~A}$ and $16 \mathrm{mg} / \mathrm{kg}$ of paclitaxel (dose ratio=2:1) showed significant therapeutic effects. We also found that by adjusting the doses and dose ratio of the agents is very important to realize oral HM30181A and paclitaxel treatment in brain tumors. These results supply useful data in realizing oral paclitaxel treatment on tumors in the brain.

\section{Acknowledgements}

This study was supported by The Korea Research Foundation Grant funded by the Korean Government (MOEHRD) (KRF2004-042-E00084), and Samsung Biomedical Research Institute (C-A7-411-1).

\section{References}

1. Kartner N, Riordan JR and Ling V: Cell surface P-glycoprotein associated with multidrug resistance in mammalian cell lines. Science 221: 1285-1288, 1983.

2. Cordon-Cardo C, O'Brien JP, Boccia J, Casals D, Bertino JR and Melamed MR: Expression of the multidrug resistance gene product (P-glycoprotein) in human normal and tumor tissues. J Histochem Cytochem 38: 1277-1287, 1990.

3. Juliano RL and Ling V: A surface glycoprotein modulating drug permeability in Chinese hamster ovary cell mutants. Biochim Biophys Acta 455: 152-162, 1976.

4. Abbott NJ and Romero IA: Transporting therapeutics across the blood-brain barrier. Mol Med Today 2: 106-113, 1996.

5. Abbott N: Astrocyte-endothelial interactions and blood-brain barrier permeability. J Anat 200: 527, 2002.

6. Beaulieu E, Demeule M, Ghitescu L, and Beliveau R: Pglycoprotein is strongly expressed in the luminal membranes of the endothelium of blood vessels in the brain. Biochem J 326: 539-544, 1997.

7. Schinkel AH, Smit JJ, van Tellingen O, et al: Disruption of the mouse mdrla P-glycoprotein gene leads to a deficiency in the blood-brain barrier and to increased sensitivity to drugs. Cell 77: 491-502, 1994.

8. Schinkel AH, Wagenaar E, van Deemter L, Mol CA and Borst P: Absence of the mdr1a P-glycoprotein in mice affects tissue distribution and pharmacokinetics of dexamethasone, digoxin, and cyclosporin A. J Clin Invest 96: 1698-1705, 1995.
9. van Asperen J, Schinkel AH, Beijnen JH, Nooijen WJ, Borst P and van Tellingen $\mathrm{O}$ : Altered pharmacokinetics of vinblastine in Mdr1a P-glycoprotein-deficient mice. J Natl Cancer Inst 88: 994-999, 1996.

10. Fellner S, Bauer B, Miller DS, et al: Transport of paclitaxel (Taxol) across the blood-brain barrier in vitro and in vivo. J Clin Invest 110: 1309-1318, 2002.

11. Gallo JM, Li S, Guo P, Reed K and Ma J: The effect of Pglycoprotein on paclitaxel brain and brain tumor distribution in mice. Cancer Res 63: 5114-5117, 2003.

12. Aisner J: Overview of the changing paradigm in cancer treatment: oral chemotherapy. Am J Health Syst Pharm 64: S4-S7, 2007.

13. Browder T, Butterfield CE, Kraling BM, Shi B, Marshall B, O'Reilly MS and Folkman J: Antiangiogenic scheduling of chemotherapy improves efficacy against experimental drugresistant cancer. Cancer Res 60: 1878-1886, 2000.

14. Folkman J: Angiogenesis and apoptosis. Semin Cancer Biol 13: 159-167, 2003.

15. Helgason HH, Kruijtzer CM, Huitema AD, et al: Phase II and pharmacological study of oral paclitaxel (Paxoral) plus ciclosporin in anthracycline-pretreated metastatic breast cancer. Br J Cancer 95: 794-800, 2006.

16. Kesari S, Schiff D, Doherty L, et al: Phase II study of metronomic chemotherapy for recurrent malignant gliomas in adults. Neuro Oncol (In press).

17. Hajek R, Vorlicek J and Slavik M: Paclitaxel (Taxol): a review of its antitumor activity in clinical studies Minireview. Neoplasma 43: 141-154, 1996.

18. Grant DS, Williams TL, Zahaczewsky M and Dicker AP: Comparison of antiangiogenic activities using paclitaxel (taxol) and docetaxel (taxotere). Int J Cancer 104: 121-129, 2003.

19. Belotti D, Vergani V, Drudis T, et al: The microtubule-affecting drug paclitaxel has antiangiogenic activity. Clin Cancer Res 2: 1843-1849, 1996.

20. Pasquier E, Carre M, Pourroy B, Camoin L, Rebai O, Briand C and Braguer D: Antiangiogenic activity of paclitaxel is associated with its cytostatic effect, mediated by the initiation but not completion of a mitochondrial apoptotic signaling pathway. Mol Cancer Ther 3: 1301-1310, 2004

21. Sparreboom A, van Asperen J, Mayer U, et al: Limited oral bioavailability and active epithelial excretion of paclitaxel (taxol) caused by P-glycoprotein in the intestine. Proc Natl Acad Sci USA 94: 2031-2035, 1997.

22. van Asperen J, van Tellingen O, Sparreboom A, Schinkel AH, Borst P, Nooijen WJ and Beijnen JH: Enhanced oral bioavailability of paclitaxel in mice treated with the Pglycoprotein blocker SDZ PSC 833. Br J Cancer 76: 1181-1183, 1997.

23. Martin C, Berridge G, Higgins CF, Mistry P, Charlton P and Callaghan R: Communication between multiple drug binding sites on P-glycoprotein. Mol Pharmacol 58: 624-632, 2000.

24. Kemper EM, van Zandbergen AE, Cleypool C, Mos HA, Boogerd W, Beijnen JH and van Tellingen O: Increased penetration of paclitaxel into the brain by inhibition of $\mathrm{P}$ Glycoprotein. Clin Cancer Res 9: 2849-2855, 2003.

25. Paek IB, Ji HY, Kim MS, Lee GS and Lee HS: Simultaneous determination of paclitaxel and a new P-glycoprotein inhibitor HM-30181 in rat plasma by liquid chromatography with tandem mass spectrometry. J Sep Sci 29: 628-634, 2006.

26. Paek IB, Ji HY, Kim MS, Lee G and Lee HS: Metabolism of a new P-glycoprotein inhibitor HM-30181 in rats using liquid chromatography/electrospray mass spectrometry. Rapid Commun Mass Spectrom 20: 1457-1462, 2006.

27. Nam DH, Park K, Park C, et al: Intracranial inhibition of glioma cell growth by cyclooxygenase-2 inhibitor celecoxib. Oncol Rep 11: 263-268, 2004.

28. Andersson U, Grankvist K, Bergenheim AT, Behnam-Motlagh P, Hedman $\mathrm{H}$ and Henriksson R: Rapid induction of long-lasting drug efflux activity in brain vascular endothelial cells but not malignant glioma following irradiation. Med Oncol 19: 1-9, 2002.

29. Regina A, Demeule M, Berube A, Moumdjian R, Berthelet F and Beliveau R: Differences in multidrug resistance phenotype and matrix metalloproteinases activity between endothelial cells from normal brain and glioma. J Neurochem 84: 316-324, 2003.

30. Prevodnik A, Lilja K and Bollner T: Benzo[a]pyrene up-regulates the expression of the proliferating cell nuclear antigen (PCNA) and multixenobiotic resistance polyglycoprotein (P-gp) in Baltic Sea blue mussels (Mytilus edulis L.). Comp Biochem Physiol C Pharmacol Toxicol 145: 265-274, 2007. 
31. Salphati L and Benet LZ: Modulation of P-glycoprotein expression by cytochrome $\mathrm{P} 4503 \mathrm{~A}$ inducers in male and female rat livers. Biochem Pharmacol 55: 387-395, 1998.

32. Eyal S, Lamb JG, Smith-Yockman M, et al: The antiepileptic and anticancer agent, valproic acid, induces P-glycoprotein in human tumour cell lines and in rat liver. Br J Pharmacol 149: 250-260, 2006.

33. Fardel O, Lecureur V, Corlu A and Guillouzo A: P-glycoprotein induction in rat liver epithelial cells in response to acute 3methylcholanthrene treatment. Biochem Pharmacol 51: 1427-1436, 1996.
34. Theron D, Barraud de Lagerie S, Tardivel S, et al: Influence of tumor necrosis factor-alpha on the expression and function of P-glycoprotein in an immortalised rat brain capillary endothelial cell line, GPNT. Biochem Pharmacol 66: 579-587, 2003.

35. Berger W, Elbling L, Minai-Pour M, Vetterlein M, Pirker R, Kokoschka EM and Micksche M: Intrinsic MDR-1 gene and P-glycoprotein expression in human melanoma cell lines. Int J Cancer 59: 717-723, 1994

36. Thomas $\mathrm{H}$ and Coley HM: Overcoming multidrug resistance in cancer: an update on the clinical strategy of inhibiting Pglycoprotein. Cancer Control 10: 159-165, 2003. 